\title{
RUSSIA TURNING ON LATIN AMERICA
}

\author{
Yuri Paniev ${ }^{l}$
}

Aromatic coffee, ripe bananas, fancy orchids, fiery samba, soap operas - this is kind of standard Russian associations, which arise when Latin America is mentioned. And although the peak of cooperation between the Soviet Union and the "flaming continent" was left behind in the 1970's, the modern Russia is catching up. As a result the Latin American direction has become, perhaps, the most spectacular component of Moscow's international activities in recent years.

Billions of dollars in contracts, joint projects in various spheres, state-of-the art technologies - this is what brings together Russia and Latin American states today. Russia has diplomatic relations with all of the 33 countries in the region, with 18 of them it has agreements based on new cooperative principles - nothing of the kind has ever existed before. Some analysts predict a new "golden age" for Russia Latin American cooperation.

According to Vladimir Davydov, the director of the Institute of Latin America and corresponding member of the RAS, the unprecedented intensity of Russia-Latin American dialogue is due to the fact that Russia's leaders have realized the strategic importance of Latin America. "For years the initiative was coming from Latin America, the Latin Americans were coming, breaking through with their exports, seeking to raise the level of political contacts. Moscow was reacting... without real inspiration", noted Davydov. "Fortunately, the situation has changed drastically"2.

Nowadays Russia has the concept of its foreign policy, approved on July 12, 2008, which directly reflects Moscow's desire to build up political and economic cooperation with the countries of Latin America and the Caribbean, expand cooperation with them in the international organizations, promote exports in the region of high-tech industrial products, carry out joint projects in energy,

\footnotetext{
${ }^{1}$ One of the great experts on Latin America, Russian Academy of Sciences (RAS). (austral@ufrgs.br)

2 "Gazeta", M., 21-23.11.2008
} 
infrastructure, high technologies, including those that make part of the plans, developed by the regional integration associations ${ }^{3}$.

Talking about factors conducive to the rapprochement of Russia with Latin America, Russia's foreign minister Sergey Lavrov noted the similarity of views on key international problems. "With Latin American partners we step forward as natural allies on such issues as the need to ensure the supremacy of international law, the strengthening of multilateral mechanisms for the solution of international problems, UN's central role, the search of collective answers to challenges of the modern world", - stressed Lavrov. "We also have common approach regarding the reform of the world financial architecture" 4 .

In addition, the mutual approach takes place due to a number of similar features in social and political development in the recent past and the present time. This important factor should be considered when analyzing the entire complex of bilateral relations.

During 2000-2011 presidents of Russia visited the Latin American region six times, foreign ministers - more than ten times. In turn, just in 2009 our country was visited by the presidents of Bolivia, Brazil, Venezuela, Cuba, Chile and Ecuador. Meetings at the level of prime ministers and heads of diplomatic departments take place on a regular basis, as well as contacts with Latin American leaders in the course of different international forums. During this period more than 200 joint documents covering various aspects of cooperation were signed. Michelle Bachelet, the ex-president of Chile, who visited Moscow twice, even suggested the idea of turning Chile into kind of a platform to enhance Russia's cooperation with Latin America $^{5}$.

Special mention should be made of Brazil, with which Russia has developed partnership within the framework of BRICS coalition, which also comprises China, India and South Africa. These are the so-called second-tier giants accounting for $25 \%$ of world GDP, $30 \%$ of the Earth's territory, and $45 \%$ of the world population ${ }^{6}$. These countries are closely cooperating at the international venues, including the recently established G-20, which is steadily supplanting the once omnipotent G-8. There is a lot of sense in BRICS definition made by Vadim Lukov, Russian negotiator and special envoy. He termed BRICS as the "reformers" alliance", having

\footnotetext{
3 The Concept of Foreign Policy of the Russian Federation. - http:/www.mid.ru/ns-osndoc.nsf/

4 "Latin America", M., 2009, № 2

5 "President", M., 16-22.09.2010

6 "International Life", M., 2011, № 6
} 
in mind their common focus on the reorganization of key international and primarily financial institutions?

It is important that currently Russia is developing constructive relations not just with the individual countries of Latin America. It has also established stable contacts with regional political associations, including the "Rio Group", the Organization of American States, the Latin American integration system. These structures have Russian observers, who produce recommendations regarding methods and ways of intensifying this cooperation.

Russia's Policy in Latin America has become by far more intense. Among new important developments here is the growth of private business activity, which is considering the region not only as a source for imported goods - primarily food products, but also a sizable market for Russian industrial goods, including high-tech, as well as promising area for investment. After all, Latin America comprises rather huge and solvent market amounting to half a billion of consumers. A good example of such developments can be the creation of the fourth generation mobile communications network in Nicaragua by a Russian company "Yota", which in terms of quality left behind the services of other competitors.

The business interest in Latin America is being boosted by positive developments in the economy of a number of countries, the acceleration of GDP growth and the volume of external trade, as well as the prominent role of these states in WTO and other influential international organizations. Most Latin American countries have been able to withstand the shock of the global economic crisis of 2008-2009 by adopting effective anti-crisis programs and thereby confirming their increased economic and financial stability. It is iqually important that Latin American businessmen have been actively accessing our market establishing customer and partnership relations in Russia. As a result the "Latin American accent" in the Russian foreign trade and foreign economic relations is becoming increasingly more distinct.

The accumulated experience of business cooperation testifies that the economies of Russia and the majority of Latin America states complement each other: the Latin Americans require Russian exports and vice versa. This, undoubtedly, is a positive macroeconomic situation which has developed quite naturally. However, while being implemented these favorable preconditions are still experiencing a lot of difficulties. No wonder that almost all the documents on the

\footnotetext{
7 “Independent Newspaper”, M., 5.03.2012
} 
results of the visits of any level include the provision that the current level of Russian-Latin American economic ties is still out of keeping with the potential.

Such claim has every reason to exist. Firstly, Russian business in most Latin American countries is still poorly known, and the business image of Russian enterprises often leaves much to be desired. The most important channel in marketing commercial proposals and investment projects for the leading Russian companies remains within the framework of top-level official visits to the region. This was the case, for example, during the trip of Vladimir Putin to Mexico, Brazil and Chile in 2004 and Dmitry Medvedev's visit to Peru, Brazil, Venezuela and Cuba in 2008. Secondly, Russian entrepreneurs face tough competition from the Western, and recently from the Chinese companies. Both of these actively resort to their governments in case of difficulties and use every type of resources to establish relationships with local authorities and media in order to secure the most favored treatment. Thirdly, the structure of Russian exports to Latin America tend to become more primitive than before. For quite a while the basis of Russian supplies to the region is formed by goods attributable to the group of semi-finished products including fertilizers, rolled steel, paper and cardboard products. In certain categories of hi-tech products Brazil and Mexico have left Russia far behind. It is hard to believe, but just 20 years ago the situation was completely different: out of 25,3 thousand cars imported by Brazil 23,1 thousand were made by Russian VAZ manufacturer ${ }^{8}$.

Finally, the system of mutual settlements, investment and scientific and technical cooperation remain vulnerable even though the high-tech industry is exactly what can become a locomotive of successful partnership. In this respect both Moscow, and Latin American capitals set their hopes upon the so-called technological alliance. In case of Brazil, for example, such alliance is most likely to reveal itself in aerospace industry. The more so, because as far back as in 2006 the parties signed an agreement on mutual protection of technologies in the area of space exploration and use of outer space for peaceful purposes. The Brazilians are interested in using our technology to produce liquid fuel for their launch vehicles. It is less explosive hazardous than the dry fuel and will allow to avoid the tragedy which occurred at the Brazilian Alcantara launch area in 2003, when 21 people were killed.

8 "Moscow News", M., 22-28.12.2006 
Russia's trade with Latin American countries (in mln USD)

\begin{tabular}{|l|l|l|r|r|}
\hline Country & \multicolumn{1}{|c|}{1992} & 2000 & $\mathbf{2 0 0 8}$ & $\mathbf{2 0 1 0}$ \\
\hline $\begin{array}{l}\text { Whole } \\
\text { region }\end{array}$ & 1330,3 & 5669,7 & 15935,0 & 12260,0 \\
\hline Argentina & 150,5 & 122,9 & 1975,9 & 1124,1 \\
\hline Brazil & 146,8 & 645,9 & 6711,2 & 5874,5 \\
\hline Chile & 22,4 & 19,5 & 364,7 & 356,6 \\
\hline Cuba & 832,1 & 385,2 & 265,1 & 276,0 \\
\hline Ecuador & 14,9 & 185,2 & 935,7 & 974,1 \\
\hline Mexico & 19,0 & 156,7 & 1230,9 & 768,8 \\
\hline Peru & 19,2 & 35,7 & 327,6 & 328,0 \\
\hline Venezuela & 22,1 & 67,7 & 957,8 & 165,3 \\
\hline
\end{tabular}

Source: Federal Customs Service of the Russian Federation. Customs foreign trade statistics for the respective years.

As seen from the chart it is Brazil which holds the first place in Russia's trade turnover with the Latin American countries. If in the cold-war period the motivation of the Soviet leadership to develop relations with Latin America had a distinctly ideological tint, and the leading trade and economic partner in the region, which has never distinguished itself by high economic indicators, was Cuba, these days, when pragmatic approach has replaced ideology, the main partner is Brazil, rightfully considered to be the "regional superpower".

Brazilian ex-president Fernando Enrique Cardoso used to emphasize that Brazil is sort of 'tropical Russia' and that these two countries have a lot in common. And the similarity not only applies to parameters such as the size of the territory and population, but to main macroeconomic indicators as well. Russia and Brazil occupy similar positions in the international division of labor acting as importers of advanced technologies and capital. There is also a coincidence of goals in the foreign policy, which include the formation of a new polycentric international system and the deepening of integration processes on the regional level.

June 22, 2000 will surely become a landmark in the history of RussianBrazilian economic relations. Firstly, because on that day a long-awaited meeting of the Russian-Brazilian high-level commission on cooperation took place in Moscow (at that time we had commissions of such a rank only with Ukraine, Italy, France and the US). Secondly, important documents were signed, which regulate the relations between the two countries until present. Thirdly, in the Russian capital the representatives of business circles of both countries met together at a businessseminar of unprecedented scale. All this gave reason for the president of the 
Brazilian-Russian chamber of industry, trade and tourism Gilberto Ramos to say: "After a long period of courting our countries, finally, have formalized relations and celebrated a wedding" 9.

As a result, in ten years the turnover increased by more than 6 times and according to the Brazilian ministry of development, industry and foreign trade exceeded 6 billion USD in 2010. However, the Russian share in the overall trade turnover of the South American giant still accounts for only 2,2\% $\%^{10}$. Despite the huge potential in trade, the product range remains quite narrow. Currently Russian deliveries to the Brazilian market are limited to raw materials and goods with low degree of processing: fertilizers and nickel.

As for Brazilian exports to Russia, its structure is very different from exports to developed countries, which have become major consumers of the Brazilian industrial production. Modernization in Brazil is still occurring at a much faster pace than in Russia. The country has achieved leadership in a number of areas, above all, in production of alternative fuel. Today Brazil is the world's \#3 aircraft exporter, a serious player in the field of genetics and deep-sea drilling technologies. Brazil is able to develop its oil fields on the continental shelf on its own and within a few years will become the largest exporter of hydrocarbons.

In the meantime for Russia, Brazil remains as an old fashioned supplier of coffee, sugar, soy, frozen chicken and meat, which account for more than $90 \%$ of total imports. And moreover, the Brazilian manufacturers are facing the problem of massive falsifications of instant coffee in Russia as well as periodic prohibitions on imports of beef and pork due to veterinary and other reasons. In a country where according to statistics there is a cow per each of the 190 million inhabitants, the meat theme became a serious political issue, damaging Russian-Brazilian relations. Brazil is one of the leading meat suppliers to Russia and according to the Institute of agromarketing in 2010 its share accounted for $35 \%$ of Russian pork imports (215 thousand tons), $45 \%$ of beef (269 thousand tons), and 19\% of poultry (121 thousand tons $)^{11}$.

In order to give new impulse to cooperation, Moscow and Brasilia are in the process of developing payment mechanisms based on national currencies. In the foreseeable future Russia and Brazil plan to abandon the US dollar as a universal

\footnotetext{
9 “Time MN", M., 23.06.2000

${ }^{10}$ Ministerio do Desinvolvimento, Industria y Comercio Exterior. Intercambio commercial brasileiro con Russia. Brasilia. Doc. RT_102, 10/01/2011

11 On meat imports prohibition from 89 Brazilian producers to RF starting from June 15, 2011. http://www.agronews.ru/newsshow.php?NId=66514
} 
means of settling their transactions. Brazil has been successful in adopting this approach to Argentina: both countries switched to their respective currencies as a means of payment in bilateral trade within the framework of MERCOSUR association.

2010 marked a 125-year anniversary of Russia-Argentine diplomatic relations. Therefore, the visit of President Dmitry Medvedev to Argentina in April of 2010 - the first ever trip of top Russian official to this country - had symbolic significance, as was noted in the joint statement after the talks. Most important, however, was the "material content" of the visit. Negotiations with President Cristina Fernandez de Kirchner and documents signed in Buenos Aires afterwards put on record a wide range of existing relationships and identified the most promising areas for future cooperation. In particular, the package of agreements provides for ${ }^{12}$ :

- $\quad$ cooperation in the area of peaceful use of atomic energy, including possible cooperation with "Rosatom" regarding the construction of "Atucha III" nuclear power plant;

- agreement between the Federal Space Agency ("Roskosmos") and the National Commission on Space Activities (CONAE) on cooperation in use and development of Global Navigation Satellite System - GLONASS;

- joint action on behalf of Saturn Scientific and Production Association and the Government of the Province of Buenos Aires for the modernization of "July 9 Thermal Power Plant";

- participation of Russian Railways JSC in modernization of the Argentine railway network;

- participation of "All-Russia Research Institute of Geology Overseas" in the field of geological studies of hydrocarbons and minerals in Argentina;

- intent to cooperate in the field of forestry.

In addition to that a memorandum on cooperation between business organizations of the two countries was signed and President Medvedev attended the

12 Documents signed as a result of Russia-Argentina talks, April 15, 2010. http://news.kremlin.ru/ref_notes/522/print 
business meeting of representatives of leading Russian and Argentine companies and banks delivering the keynote address. "We came close to practical implementation of projects in high-tech fields including nuclear, space, energy and transport infrastructure. Here on our side you have the heads of major Russian companies, public and private. We already have had success stories cooperating in the energy area. Today, a quarter of Argentina's power is being generated by Russian turbines $" 13$.

Diplomatic circles also paid attention to Medvedev's words underlining that "Russia has returned to South America" making it "quite vigorously" and is now actively developing relations with Latin American partners. "It is evident that Russia's position in relation to Latin America has changed", Medvedev said. "We believe that here live our friends, people who are close to us, and we would like to cooperate with them more closely "14.

Russia offered its technologies to Argentina not only in the energy sector, where there already is experience of cooperation but also in such areas as railway transport (almost half of the country's railroads are not operational), the research of Antarctica, where Russian icebreakers and helicopters are in demand, space exploration, and peaceful use of nuclear energy. According to Medvedev, the arrival of "Rosatom" in the Argentinean market will entail multi-billion dollar investments targeting the construction of respective power generating units as well as infrastructural development. Such projects create the so-called multiplier effect, that is, make it possible to develop related sub-industries, new manufacturing facilities and jobs.

The fact that cooperation with Russia helps to reduce unemployment - a painful problem for Latin America - was quite convincing in case of Venezuela. The arrival of Russian state and private corporations, such as "GazpromNeft", "Rosneft", "LUKoil", "Surgutneftegas", TNK-BP contributed to creating thousands of new jobs in the country. Russian energy majors, which together with the Venezuelan state company "Petroleos de Venezuela" have formed the National Oil Consortium (PNC) are getting ready to extract "black gold" at Junin-6 field in the oil-rich area of Orinoco's delta (the estimated crude resources amount to $53 \mathrm{bln}$. barrels). The development of this rich field will take about 40 years and require total

\footnotetext{
13 "Pagina 12", Buenos Aires, 15.04.2010

14 "Russian Newspaper", M., 16.04.2010
} 
investment of 20 bln. dollars ${ }^{15}$. Just for getting access to "Carabobo-2" oilfield, as was agreed in October 2011, "Rosneft" committed 1 bln. dollars ${ }^{16}$.

The main feature of the Russia-Venezuela cooperation is that it is developing under the umbrella of a president Chavez-led, ideologically pronounced "Bolivarian project", which aims to build socialism of the XXI century in one country. Hence, Venezuela's drive to put its cooperation with Moscow into the context of anti-US discourse, which sometimes strains the Russian government and, in practice, certainly creates new geopolitical environment in the Caribbean.

During the years of his presidency, Chavez visited Russia nine times. While welcoming the Venezuelan leader in 2001, Putin said: "The cooperation with Venezuela is a fundamental element of Russia's relations with Latin America"17. At that point political dialogue between the two countries began to take shape along with the main areas of economic cooperation: oil and gas, chemicals and petrochemicals, joint development of natural resources, and military cooperation. Over the years both sides have accomplished tangible results in all these areas, turning Venezuela into Russia's privileged partner in the region.

Venezuela has become number two buyer of Russian military equipment in the world after India. According to the Center for Analysis of Global Arms Trade the cost of Russian arms and military equipment purchased by Caracas is estimated at $\$$ 4.4 billion. It includes 24 Su-30MK2V fighter jets, 100,000 AK-103 submachine guns, more than 40 multi-functional Mi-17V-5 helicopters, 10 Mi-35M2 attack helicopters, 3 Mi-26T2 heavy transport helicopter, 5,000 SVD sniper rifles, 12 "TorM1" air-defense missile systems, ZU-23-2 anti-aircraft gun, a batch of "Igla-S" portable anti-aircraft missiles. According to ANV news agency in August 2011 Venezuela received another batch ZU-23 anti-aircraft guns, portable mortars and armored vehicles. According to Venezuelan Defense Minister Carlos Mata Figueroa "we need these weapons to be able to defend our country"18.

Judging by the results of negotiations, in which Russian Deputy Prime Minister Igor Sechin participated in October 2011 in Caracas, Venezuela will receive another $4 \mathrm{bln}$. dollar loan from Russia to modernize its armed forces. According to Chavez "it will be 2 billion next year and 2 billion in 2013". "We can do it today because we are free, - said the Venezuelan leader. - "We could not have done this

\footnotetext{
15 "Vedomosti", M., 2.02.2010

16 "Commersant", M., 8.10.2011

${ }^{17}$ Bilivarian Project and Prospects for Russia-Venezuela Partnership", M., 2005, c. 40.

18 “Independent Newspaper", M., 19.08.2011
} 
before, because we were dominated by Yankees, the World Bank and the entire imperial economy and financial structure"19.

Freedom from the West Caracas sees in transferring its financial reserves from the U.S. and Europe to its own central bank, as well as to countries such as Russia, Brazil and China. It is assumed that these funds will serve as a guarantee for loans which Venezuela needs. According to various estimates, up to 6 billion dollars could flow from Venezuela to Russia, more than half of which is kept in Switzerland while the remainder is kept in U.S., British and French banks. According to the Central Bank of Venezuela, its foreign exchange reserves amount to $29.9 \mathrm{bln}$. dollars, 18.3 billion of which are in gold ${ }^{20}$. In Venezuela they are convinced that in the foreseeable future these reserves will increase significantly since country's leadership decided to nationalize gold exploration and mining.

Talking about the present-day Russia's key partners in Latin America, one cannot forget about yesterday's closest ally and friend - Cuba. In the post-Soviet period of Russian-Cuban cooperation, which for 30 years played the role of support structure in political and economic strategy of the Soviet Union in Latin America (during 1960-1990 in Cuba the Soviet Union built more than 1,000 facilities, 100 of them being large industrial enterprises), has decreased dramatically in all spheres.

In 1991 Moscow informed Havana that it was recalling all seven thousand of its technical personnel in one month, freezing all the construction projects, and refusing every support in both civil and military spheres. The evacuation took place in front of astonished and disoriented Cubans exactly the way the American experts were fleeing the country before the arrival of Che Guevara's rebel army at Havana. As a result, all the activity was stopped at the most important industrial projects including Jose Marti metallurgical plant, "Las Camariocas" nickel plant, the "Havana" TPP, in the construction of which huge expenses were made. Just to build the Jaragua nuclear power plant the Soviet Union spent about 1.2 bln. dollars ${ }^{21}$.

The last Russia's major "surrender" in Cuba occurred in 2003, when the radio-electronic surveillance center in Lourdes, which allowed Russian specialists to eavesdrop telephone calls and emails across the United States, was shut down. In fact, it could be said that Russia rejected Cuba and left it to its devices. But the Cubans, despite the expectations of those who oppose the regime of Fidel Castro

\footnotetext{
19 "El Universal", Caracas, 7.10.2011

20 "The Financial Times", London, 17.08.2011

21 "Latin America in Current World Politics", M., 2009. c. 524
} 
have survived without giving up ideological principles and their persistence in building socialism.

The new geopolitical situation in the world and the changes in Latin American politics have prompted Moscow to seek ways to restore Russian-Cuban relations. The first attempt to revive cooperation was made in September of 2006 during the visit of then Russian Prime Minister Mikhail Fradkov to Cuba, which settled the issue of Cuba's debt to Russia amounting to $166 \mathrm{mln}$. dollars and lodged a loan for the purchase of Russian equipment and spare parts amounting to $355 \mathrm{mln}$. dollars $^{22}$.

President Medvedev's visit to Havana in November 2008 marked the beginning of a new stage in Russian-Cuban relations. Recalling that in Soviet times the relations with Cuba were "quite powerful" Medvedev said: "Now it is time to restore them" 23 .

In 2009 the Chairman of the State Council and the Council of Ministers of Cuba Raul Castro came to Moscow. During the visit a memorandum on the principles of cooperation was signed, which has laid the foundation for revitalization of bilateral cooperation. The agreements included joint actions to create a fair and polycentric world order, implementation of a number of major projects, primarily in the area of energy, transport, civil aviation, biopharmaceuticals and high-tech.

It seems that the long pause in Russian-Cuban relations is over. But it is also obvious that the new level of cooperation will require constant efforts on both sides. Moreover, our companies will have to retake what was once carelessly abandoned by Russia without bothering to count the losses. Oil explored by Soviet specialists on the shelf, in which considerable resources were invested, is now produced by Canadians, French and Malaysians. As a result, "GazpromNeft", for example, had no other option but to sign an agreement with Malaysian company "Petronas", according to which it received a 30 percent share in the joint offshore exploration and production in Cuba's sector of the Gulf of Mexico. Proven oil reserves in this area are small and amount to $260 \mathrm{mln}$. tons. However, the total reserves are much larger: "Cubapetroleo" estimates the reserves to be as high as $2.7 \mathrm{bln}$. tons, the U.S. Geological Survey - 1.2 bln tons of oil and 21 trillion cubic meters of gas ${ }^{24}$.

A unique situation has come into being in Russia's relations with Ecuador: a direct container route linking Guayaquil and St. Petersburg was opened. There are

\footnotetext{
22 "Vremya Novostei", M., 29.09.2006

23 "Russian Newspaper", M., 27.11.2008

24 “Expert”, M., 2010, № 46
} 
ongoing investment projects in agriculture and food industry. Banana producers of Ecuador have the opportunity to develop production using investments from Russia. Investments are also made to develop production facilities for banana's processing and packaging.

It should also be pointed out that in Latin American countries students have maintained an interest in studying in Russia, though not on a scale typical for the Soviet era. Currently just hundreds of students are interested to come to study different specialties in Russia. There are certain difficulties associated with covering travel expenses and getting decent scholarship. However, these complex issues can be resolved. The graduates from Russian universities have created their own associations in various countries of Latin America, making a considerable contribution to the development of bilateral cooperation identifying approaches to new areas.

The new Russian policy in Latin America spurred waves of polar opinions and comments in the region and beyond. Many Western observers believe that the revitalization of Moscow's policy in the region is a geopolitical course designed to recuperate the great power status directed against the United States while the arms sales to Venezuela is contributing to escalation of arms race in the region. Some also reason that Russia's activity in Latin America is just a balanced response to the expansion of the West in the CIS.

Indeed, while promoting cooperation with Latin America Russia is guided by geopolitical considerations. My country, however, is not unique when looking for ways to expand its presence in the world using the growing trade and economic opportunities and demands. This also applies to military cooperation and not just with Venezuela, but also with such countries as Argentina, Bolivia, Brazil, Peru and Chile, with which corresponding agreements were signed during 2004-2009. As a major producer and exporter of weapons, Russia, naturally, is looking for new markets for its products including those in Latin America. All the allegations that it is contributing to arms race do not stand up to criticism. Here is just one eloquent fact: the regional leader in military spending is Colombia (4\% of GDP), while Venezuela spends no more than $1.3 \%$ of its GDP ${ }^{25}$. However, arms to Colombia are not coming from Russian, they come from the United States and France, both, incidentally, being the leading exporters the Latin American arms market. Up to this point Russia has only managed to get to the third place in Latin America.

25 "Nueva Sociedad", Buenos Aires, 2010, N 226, p. 9 
Nonetheless, Russia's political reasoning might be totally different. Latin American countries have been consistently increasing their economic potential, their role in world affairs is steadily enhancing. The examples are not far to seek: Mexico and Chile have joined the Organization for Economic Cooperation and Development (OECD), a grouping of the most developed nations, while Argentina, Brazil and Mexico are now part of G20. In fact we are witnessing how another center in the multi-polar world is emerging, and this is something impossible to ignore. Moreover, Russia and Latin American countries claim a more significant role in global economic and financial regulation. Only joint efforts and constructive interaction with other ascending states will help to achieve this goal. Here is what President Medvedev said describing the geopolitical importance of Latin America: "To certain extent we are just at the beginning of a robust, full-scale and mutually beneficial relationship with partners in Latin America. There is no reason to be scrupulous and afraid of competition. We should just jump into fray"26. By "fray" he obviously meant competition - the United States are traditionally present in the region, same as Western Europe, and recently China. The emergence of Russia in Latin America is just a new geopolitical reality, the evidence of its global interests. 


\begin{abstract}
This paper describes the current relations of Russia with main Latin American countries: Brazil, Argentina, Venezuela and Cuba in the commercial, economical and military scope. The author calls the attention to the real intentions of Russia's approximation policy with the continent: would the geopolitics partners be allies in recuperate the Russian status of directed power against the United States, or just a smart play due to the emergence of new powers in this multi-polar world?
\end{abstract}

\title{
KEYWORDS
}

Russia; Latin America; Strategic partnerships; Multipolar-world; 